\title{
Removal of Defendants in Federal Criminal Procedure
}

\author{
Alexander Holtzof*
}

A unreve phase of federal criminal jurisprudence has been the hended in a judicial district other than that in which the case is to be tried. The Sixth Amendment to the Constitution guarantees to the accused the right to a trial in the state and district wherem the crime shall have been committed. Consequently, if he is discovered in another district, he may not be tried there. A way must be found to transport him to the proper jurisdiction.

The importance of this aspect of the administration of federal criminal law has gradually grown with the vast territorial expansion of the United States, as well as with the prodigious increase in the number of criminal offenses cognizable in the courts of the United States. The renoval of a defendant from one judicial district to another is in primcipal far different from foreign extradition, and even from interstate rendition. In the case of foreigu extradition, two distinct sovereiguties are involved. In the case of interstate rendition, a state of the Union, clothed with certain aspects of sovereignty, is requested to surrender a person for trial by another state. In the case of removal of a defendant from one federal judicial district to another for trial in a federal court, only a simgle sovereign is concerned. The problem is neerely one of transporting the defendant from one territorial subdivision to another.

It may be argued that because of this distinction the law governing the removal of defendants is an unnecessary excrescence in federal criminal procedure. Logically there seems to be no valid reason why a person who has been arrested on a federal charge lodged against him in a district other than that in which he is taken into custody, should not be forthwith brought by the arresting officer before the court in which the case is pending, without the necessity of resorting to a special legal proceeding for that purpose. Analogy to state procedure supports this line of reasoning. A person arrested by state or local authorities in a county other than that in which the

* Special Assistant to the Attorney General of the United States; Secretary, Advisory Committee on Federal Rules of Criminal Procedure. 
accusation has been filed is not entitled to a hearing in order to determine whether he may be removed to the county in which the prosecution has been instituted. Removal automatically follows arrest. There are practical considerations, however, that must be weighed as against the purely theoretical approach. In view of the large expanse of the United States, considerable unnecessary hardship may result from an improvident removal of a defendant from one federal jurisdiction to another, if the two are hundreds or thousands of miles apart, as is frequently the case. At the very least, steps should be taken to assure at the outset that the person arrested is actually the accused. To discover an error in identity at the end of a long journey would indeed be lamentable. On the other hand, the interposition of technicalities to hinder, obstruct or postpone removal at times results in a frustration, or at least a delay, of justice. This consequence is especially apt to occur in cases im which removal is between adjoining districts and comprises but a short distance.

At the outset it must be observed that there is no constitutional requirement that a defendant whose removal is sought be accorded a hearing on this question. In fact, there is no constitutional mandate that there should be any removal proceedings whatever. ${ }^{1}$ The law on this subject origimated in an early statute of a somewhat general and indefinite character. This enactment has been expanded and elaborated by numerous decisions of the courts. The result is that the law of removal in federal criminal procedure is an edifice constructed almost entirely by judicial decisions.

A discussion of this subject must commence with a consideration of the goverming statute, which dates back to 1789 and remains practically unchanged to this day. The original provision is found in Section 33 of the Judiciary Act of 1789, the pertinent.portions of which read as follows:

"That for any crime or offence against the United States, the offender may, by any justice or judge of the United States, or by any justice of the peace, or other magistrate of any of the United States where he may be found agreeably to the usual mode of process against offenders in such state, and at the expense of the United States, be arrested, and imprisoned or bailed, as the case may be, for trial before such court of the United States as by this act has cognizance of the offence.... And if such commitment of the offender, or the wit-

1 United States ex rel. Hughes v. Gault (1926) 271 U.S. 142; United States ex rel. Kassin v. Mulligan (1935) 295 U.S. 396. 
nesses shall be in a district other than that in which the offence is to be tried, it shall be the duty of the judge of the district where the delinquent is imprisoned, seasonably to issue, and of the marshal of the same district to execute, a warrant for the removal of the offender, and the witnesses, or either of them, as the case may be, to the district in which the trial is to be had."2

About three years later, the foregoing enumeration of state and local judicial officers authorized to act as federal committing magistrates was considerably enlarged. ${ }^{3}$

During the early years of the Republic the federal government had no magistrates of its own, but relied entirely on those of the states and localities. Subsequently, however, the office of United States Commissioner was created, originally known as "Commissioner of the Circuit Court". By the Act of August 23, 1842, the authority defined in Section 33 of the Judiciary Act was extended to these commissioners. ${ }^{4}$ In its present form, the provision is found in section 1014 of the Revised Statutes, and reads as follows:

"SEC. 1014. For any crime or offense against the United States, the offender may, by any justice or judge of the United States, or by any commissioner of a circuit court to take bail, or by any chancellor, judge of a supreme or superior court, chief or first judge of common pleas, mayor of a city, justice of the peace, or other magistrate, of any State where he may be found, and agreeably to the usual mode of process against offenders in such State, and at the expense of the United States, be arrested and imprisoned, or bailed, as the case may be, for trial before such court of the United States as by law has cognizance of the offense. ... And where any offender or witness is committed in any district other than that where the offense is to be tried, it shall be the duty of the judge of the district where such offender or witness is imprisoned, seasonably to issue, and of the marshal to execute, a warrant for his removal to the district where the trial is to be had."

It will be noted that except for slight changes in phraseology and for an enlargeunent of the list of committing unagistrates, the original statute of 1789 remains unaltered.

The Act applies to all arrests and commitments for federal offenses, irrespective of whether the arrest is made in the district where

21 STAT. (1789) 73, 91.

31 Stat. (1793) 333-334 (\$ 4).

45 Star. (1842) 516.

5 This provision is also found in $18 \mathrm{U}$ U.S.C. \$ 591, which substitutes the words "United States Commissioner" for "Commissioner of a Circuit Court to take bail". 
the prosecution is pending or in soine other jurisdiction. If the latter is the case, however, the statute contains an additional provision imposing on the judge of the district where the arrest is made the duty to issue a warrant for the removal of the accused to the district where the trial is to be had. The statute is silent on the question whether the issuance of a removal warrant is a purely ministerial function or requires judicial consideration and action. There is no express requirement that a hearing be accorded to the accused on the question whether a warrant of removal should be granted. ${ }^{6}$ These matters have been developed and elaborated over a long period by a series of judicial decisions.

As indicated above, section 1014 of the Revised Statutes does not deal solely with the removal of the accused from one judicial district to another, but endeavors to cover the entire field of the issuance of warrants, preliminary hearings, and commitments on a criminal charge. Our consideration, however, is restricted to the application of the statute to cases in which the defendant is arrested and bound over to answer a charge pending in another district.

Removal may be had on any criminal charge whatsoever, including a criminal contempt. ${ }^{7}$ It may take place either before or after an indictment has been found against the defendant. It may be based either on a complaint filed before a committing magistrate in the district to which removal is sought, or on an information filed by the United States Attorney in that district or on an indictment found by a grand jury. ${ }^{8}$ While ordinarily recourse is had to the statute for the purpose of removing a defendant to answer a criminal charge pending against him, its use has also been sanctioned in the case of a defendant who has been tried and convicted but who left the jurisdiction before sentence was imposed. His return under the statute was authorized for the purpose of imposition of sentence. ${ }^{9}$ Resort need not be had, however, to this procedure for the purpose of 'returning a prisoner who has been recaptured after an escape from custody.

8 United States ex rel. Hughes v. Gault, supra note 1; In re Burkhardt (E.D. Wis. 1887) 33 Fed. 25.

T United States v. Jacobi (W.D. Tenn. 1871) Fed. Cas. No. 15460; In re Ellerbe (E. D. Mo. 1882) 13 Fed. 530.

8 United States v. Haskins (D. Cal. 1875) Fed. Cas. No. 15322. At one time, however, it was the practice in the Northern District of Texas not to permit removal until after an indictment has been found in the district in which the prosecution originated. United States v. White (N.D. Tex. 1885) 25 Fed. 716.

9 Palmer v. Thompson (1902) 20 App. D.C. 273. 
It has been pointed out that in such a case the court may summarily direct his return under its general power to issue writs not specifically provided for by statute, which may be necessary for the exercise of its jurisdiction and agreeable to the usages and principles of law. ${ }^{10}$ In fact, in such a situation no judicial process appears necessary. The prisoner may be retaken and administratively returned to the custody froin which he escaped.

The removal statute is applicable to the District of Columbia. Fugitives from justice charged with a crime in the District of Columbia may be removed to the Nation's capitol from the place where they are apprehended. The reverse is likewise true. ${ }^{11}$

The first step in the process of removing a defendant for trial to another district is the institution of a criminal proceeding. Removal may not be accomplished until after the prosecution is instituted in the district to which removal is sought. There is at least one reported case, however, in which commitment and removal were ordered before institution of the prosecution in the district in which the case was to be tried. In 1807, Chief Justice Marshall, sitting as a committing magistrate in the District of Virginia, entertained a motion for the commitment of Aaron Burr and Harman Blennerhassett to another district for trial on a charge of treason. Burr demanded an examination, which was thereupon conducted. At the conclusion of the hearing the Chief Justice announced that he would commit Burr and Blennerhassett on a charge of preparing and providing the means for a military expedition against the territories of a foreign prince with whom the Uunited States was at peace. A colloquy ensued between the Chief Justice and government counsel as to the particular district to which the defendants should be committed. On motion of government counsel, the Chief Justice ordered their cominitment to Ohio.13

At one time it was the frequent practice in many districts to issue a warrant of removal almost automatically and to combine it with a warrant of arrest. The combined warrant was issued on the basis

10 In re Christian (W.D. Ark. 1897) 82 Fed. 835; U.S. REv. StaT. (1878) § 716, JUdicuat Code $\$ 262,28$ U.S.C.A. $\$ 377$.

11 United States v. Hyde (N.D. Cal. 1904) 132 Fed. 545 aff'd, Hyde v. Shine (1905) 199 U.S. 62, 84; Benson v. Henkel (1905) 198 U.S. 1; United States v. Campbell (E. D. Pa. 1910) 179 Fed. 762 ; Easterday v. McCarthy (C. C. A. 2d, 1919) 256 Fed. 651; Parker v. United States (C. C. A. 9th, 1925) 3 F. (2d) 903; United States ex rel. Coleman v. Laubenheimer (C. C. A. 7th, 1933) 67 F. (2d) 193.

12 United States v. Burr (D. Va. 1807) Fed. Cas. No. 14694a. 
of a showing that a criminal charge was pending in the district to which the defendant's removal was sought. ${ }^{13}$ When this course was pursued, the defendant obviously had no opportunity for a hearing on the question whether he should be removed to another district for trial. Upon his apprehension the arresting officer immediately transported him to the other district and brought hin before the court or a commissioner in that jurisdiction. In fact, at one time it was suggested that removal proceedings were necessary only if the arrest was made pursuant to a warrant issued by a local magistrate or a United States commissioner, but that a warrant issued by a federal judge runs throughout the United States, and if arrested pursuant to such warrant, the defendant may be immediately transported to the place where the warrant is returnable without the interjection of a removal proceeding. ${ }^{14}$ This view, however, does not seem to have been accepted, in so far as is revealed by reported cases. The practice of combiming a warrant of arrest with a warrant of removal into a single document, thereby eliminating the necessity for a removal hearmg, has been repudiated and disapproved. ${ }^{15}$

In United. States v. Shepard ${ }^{16}$ decided in the Eastern District of Michigan in 1870, the court made the following conments on this point:

"Warrant of removal is authorized only where the offender has been first arrested and committed for want of bail, in a bailable case. The statute does not seem to contemplate or warrant removing a person froin one district to another in the summary way pursued in this case. He is first to be taken before the proper officer, who is to examine as to the crime alleged against the accused. If there be not probable cause of his guilt, he is entitled to be discharged; whereas, if there be found reasonable cause for holding the accused to answer, upon tendering sufficient bail, he is entitled to his discharge from arrest. Only on failure to give bail, in a bailable case, can he be committed.

“. . . Suppose defendant had been a resident of Galveston, in Texas, or San Francisco . . . instead of Chicago, and was thus arrested and summarily removed nearly across the continent, before

13 United States v. Shepard (E.D. Mich. 1870) Fed. Cas. No. 16273; United States v. Yarborough (W.D. Va. 1903) 122 Fed. 293.

14 Opinion of Acting Attorney General Ashton rendered on December 10, 1864, 11

Or. ATTY. Gen. 127.

15 United States v. Shepard, supra note 13; United States v. Jacobi, supra note 7;

United States v. Yarborougb, supra note 13.

16 Supra note 13, at 1058; Accord: United States v. Yarborough, ibid. 
having the opportunity of meeting the charge on which he was arrested."

The accepted removal procedure consists of the following steps. A criminal proceeding is instituted in the district in which the case is to be tried. This is done either by filing a complaint before a committing magistrate, generally a Umited States commissioner, filing an information in cases which need not be prosecuted by an indictment, or finding of an indictment by a grand jury. A warrant of arrest is then issued and delivered to the marshal for service, who, if the defendant is not found within the district, returns the warrant non est inventus. When the defendant is located in another district, certified copies of the complaint, information or indictment, as the case may be, and of the warrant and the return, are transmitted to the latter district. A complaint, to which these papers are attached, is presented either to a committing magistrate or a judge in that jurisdiction, ordimarily the former, and a warrant of arrest is issued. The defendant is then apprehended and brought before a committing magistrate or a judge, again ordinarily the former. The universal practice is to institute such proceedings before United States commissioners rather than before local magistrates. The commissioner conducts a preliminary hearing or exammation on two issues: first, whether the prisoner is in fact the accused against whom the charge is pending in the district to which removal is sought; and second, whether there is probable cause to believe the prisoner guilty of the offense. If the commissioner finds for the prosecution on each of these issues, he commits the defendant to answer the charge, holding him in bail pending application for a warrant of removal. An application is then made to the district judge for a warrant of removal. The latter has authority to review the action of the commissioner and, in fact, to pass on the issues de novo. If the application for removal is granted, a warrant issues, unless the defendant gives bail for appearance in the district in which the case is to be tried. The action of the judge in granting the warrant of removal may be reviewed by a writ of habeas corpus. ${ }^{17}$ At times, habeas corpus proceedings are instituted after the commissioner holds the defendant and before a warrant of removal is issued by the judge. In such a situation, it is the frequent practice for the judge to combine the hearing on an application of the government for a warrant of removal with the hearing on the return to the writ of habeas corpus.

17 Stewart v. United States (C.C. A. 8th, 1902) 119 Fed. 89. 
Although the statute provides that "it shall be the duty of the judge ... seasonably to issue ... a warrant for his [i.e., the offender's] removal to the district where the trial is to be had", it has been repeatedly held that in spite of the mandatory phraseology of this direction the judge does not fulfill a mere ministerial duty but performs a judicial function. He passes on the issue of the identity of the prisoner with that of the person named in the criminal charge filed in the district to which removal is sought and on the issue of probable cause, and determines judicially whether the removal of the prisoner should be ordered. ${ }^{18}$

Judge Dillon, in a case decided in the Eastern District of Missouri in 1875, expressed the following views on this point:

"In a country of such vast extent as ours, it is no light matter to arrest a supposed offender, and, on the mere order of an inferior magistrate, remove him hundreds, it may be thousands, of miles for trial. The law wisely requires the previous sanction of the district judge to such removal. Mere technical defects in an indictment should not be regarded; but a district judge who should order the removal of a prisoner when the only probable cause rehed on or shown was an indictment, and that indictment failed to show any offense against the laws of the United States, or showed an offense not committed or triable in the district to which the removal is sought, would misconceive his duty and fail to protect the liberty of the citizen."19

The defendant is entitled to notice of the time and place of the application for a warrant of removal. $\mathrm{He}$ is accorded the right to appear before the judge in order to present any objections that he may have to offer. ${ }^{20}$

It is a general principle that the decision of a committing magistrate on the question whether the accused should be bound over to answer a criminal charge is not res judicata. On this basis the action of a commissioner or a judge denying an application for removal and discharging the prisoner is not deemed conclusive and is not technically a bar to a subsequent application for the same relief. The prior

18 In $r e$ Doig (D. Cal. 1880) 4 Fed. 193; In re Wolf (W.D. Ark. 1886) 27 Fed. 606; In re Price (C.C.S.D.N.X. 1897) 83 Fed. 830, af'd, Price v. McCarty (C.C.A. 2 d, 1898) 89 Fed. 84; Pereles v. Weil (E.D. Wis. 1907) 157 Fed. 419; United States ex rel. Smith v. Mathues (E. D. Pa. 1922) 284 Fed. 368; United States v. Lynn (W. D. Pa. 1922) 284 Fed. 904; United States ex rel. Brody v. Hecht (C. C. A. 2d, 1926) 11 F. (2d) 128.

19 In re Buell (E. D. Mo. 1875) Fed. Cas. No. 2102, at 588.

20 In re Beshears (S. D. Iowa 1897) 79 Fed. 70. 
disposition of the matter is, however, strongly persuasive. ${ }^{21}$ It is generally held that, irrespective of its legal effect, a determination in favor of the defendant in a removal proceeding should ordinarily preclude other applications for the same purpose, unless the earlier decision was arbitrary or was clearly the result of errors of law or unless other special circumstances are present. ${ }^{22}$

Baffling and perplexing problems arise in endeavoring to formulate definite principles as to what constitutes sufficient proof of probable cause to justify removal, to what extent such proof may be controverted by the accused and what cognate issues may be considered. For this purpose removal proceedings may be divided into two categories: first, cases in which the arrest has been made and the removal is sought merely on the basis of a complaint or information filed in the district where the charge originated; and second, cases in which the application for removal is predicated on an indictment. As to cases in the first class, it is well settled that the complaint or information filed in the district of origin is not proof of probable cause, but is merely an accusation. The onus rests on the prosecution to offer at the removal hearing evidence of probable cause sufficient to justify commitment of the defendant. ${ }^{23}$ In this respect, the situation is the same as that presented when the accused is arrested in the district where the original complaint was filed and is brought before the commissioner for a preliminary examination to determine whether he should be bound over.

The question is entirely different when the arrest is made and removal is sought on the basis of an indictment. In that event, the grand jury has heard the evidence, has found that a prima facie case exists against the defendant and has concluded that he should be brought to trial. The court to which the indictment is returned is without power to review the sufficiency of the evidence before the grand jury or the basis for its action. That court has no authority to reconsider the question whether sufficient cause exists to bring the defendant to trial. It seems incongruous that the court of another dis-

21 United States ex rel. Rutz v. Levy (1925) 268 U.S. 390; United States ex rel. Povlin v. Hecht (C. C. A. (2d), 1931) 48 F. (2d) 90.

22 In re Wood (D. Ore. 1899) 95 Fed. 288; United States v. Haas (S.D. N. Y. 1906) 167 Fed. 211; United States ex rel. Greenberg v. Epstein (E.D.N. Y. 1929) 33 F. (2d) 128.

23 United States v. Yarborough, supra note 13; United States ex rel. Kassin v. Mulligan, supra note 1. 
trict should be clothed with this power which is denied to the court in which the case is pending.

This problem has troubled the courts and has been a topic of a great deal of consideration. It is well established that the indictment may be, in itself, at least prima facie proof of probable cause and may alone justify removal if accompanied by proof of identity. In concluding whether removal should be granted on the basis of the indictment, the following issues should be determined by the court: first, whether the indictment substantially charges the commission by the defendant of an offense against the laws of the United States; and second, whether the court for the district to which relnoval is sought has jurisdiction of the case, i.e., whether the offense charged appears to have been committed in that district. Any doubts on these matters must be resolved in favor of the government. ${ }^{24}$ The legal sufficiency of the indictment as a pleading is not, however, open for consideration. Such issues are to await determination by the trial court. This is also true of disputed questions of law or fact generally. ${ }^{25}$

There has been a great deal of litigation over the question whether an indictment is more than merely prima facie proof of probable cause, but should be deemed conclusive on that issue. For the reasons heretofore indicated, much may be cogently said in support of the proposition that the indictment should be conclusive. Some of the earlier cases adopted this view, which was apparently sanctioned and followed in many districts. ${ }^{26}$ Other cases, however, held that the in-

24 In re Doig, supra note 18; United States v. Rogers (W. D. Ark. 1885) 23 Fed. 658; In re Alexander (D. Mass. 1871) Fed. Cas. No. 162 ; Horner v. United States (1892) 143 U.S. 207 ; In re Huntington (S.D. N. Y. 1895) 68 Fed. 881 ; In re Runkle (S.D. N.Y. 1903) 125 Fed. 996; Ex parte Hyde (N. D. Cal. 1904 Fed. 207; Benson v. Henkel, supra note 11; Ireland v. Henkel (S. D. N. Y. 1910) 179 Fed. 993 ; Haas v. Henkel (1910) 216 U.S. 462 ; Rowe v. Boyle (C. C. A. 9th, 1920) 268 Fed. 809; United States ex rel. Smith v. Mathues, supra note 18; United States v. Lynn, ibid.; Crossland v. Dyson (C. C.A. 5th, 1922) 280 Fed. 105; In re Parker (S.D. Cal. 1924) 299 Fed. 1006, afd, Parker v. United States, supra note 11; Looney v. Romero (C.C.A. 8th, 1924) 2 F. (2d) 22; United States v. Andrade (N.D. Tex. 1926) 10 F. (2d) 572; Bonaventura v. United States (C. C. A. 9th, 1932) 55 F. (2d) 833.

25 In re Clark (S.D. N.Y. 1868) Fed. Cas. No. 2797; In re Benson (S. D. N.Y. 1904) 131 Fed. 968; Beavers v. Henkel (1904) 194 U. S. 73; Farr v. Palmer (1904) 24 App. D. C. 234 ; United States v. Barber (W. D. Wis. 1907) 157 Fed. 889 ; United States v. Winsott (S. D. N. Y. 1908) 161 Fed. 586; United States v. Reddin (E. D. Wis. 1912) 193 Fed. 798; Conetto v. United States (C. C. A. 9th, 1918) 251 Fed. 42 ; In re Parker, supra note 24, aff'd, Parker v. United States, supra note 11; Snyder v. Hunter (D. C. 1925) 8 F. (2d) 902 ; Cochran v. Esola (C. C. A. 9th, 1933) 67 F. (2d) 91; Fetters v. United States (1930) 283 U.S. 638; United States ex rel. Kassin v. Mulligan, supra note 1.

${ }^{26}$ In re Belknap (D. Ky. 1899) 96 Fed. 614; United States v. Yarborougb, supra note 13. See also United States v. Andrade, supra note 24. 
dictment is only prima facie evidence of probable cause and while sufficient to justify removal in the absence of satisfactory evidence to the contrary, it is nevertheless open to refutation by evidence offered by the accused. ${ }^{27}$

This is one of the problems presented in a closely contested removal proceeding arising out of the celebrated prosecution of Captain Oberlin M. Carter and his associates on a charge of conspiracy to defraud the Urited States. The indictment was found in the Southern District of Georgia. A proceeding followed for the arrest and removal of several of the defendants, who were residents of the Southern District of New York. At the hearing before the commissioner, a certified copy of the indictment was introduced in evidence by the United States. The commissioner excluded proof offered by the defendants in support of their contention that they were innocent and in substantiation of their claim that the grand jury which had indicted them had been irregularly drawn. He then found in favor of the government on the issue of probable cause and committed the defendants. The district judge, however, declined to direct their removal because of the commissioner's failure to admit evidence tending to show their innocence. He held that the indictment was not conclusive on the issue of probable cause and might be contradicted by proofs to the contrary. ${ }^{28}$ The proceeding was then remitted to the commissioner, who reopened the hearing and admitted testimony offered by the defendants. At the close of the case, he again found in favor of the government and committed the defendants to await action on the application for a warrant of removal. The district judge sustained the findings of the commissioner and ordered removal..$^{20}$ The defendants then applied to the circuit court for a writ of habeas corpus, and from the order denying the application appealed to the Supreme Court. This tribunal, in affirming the denial of the writ, ${ }^{30}$ expressly left open the question whether in a removal proceeding the indictment is conclusive evidence of probable cause or is subject to refutation by evidence in behalf of the accused. The court stated that it was unnecessary to decide this question, as the commissioner had admitted the defend-

27 In re Wood, supra note 22; In re Richter (E. D. Wis. 1900) 100 Fed. 295; Pereles v. Weil, supra note 18; United States v. Campbell (E. D. Pa. 1910) 179 Fed. 762; United States v. Lynn, supra note 18.

28 United States v. Greene (S. D. N. Y. 1900) 100 Fed. 941.

20 United States v. Greene (S. D. N. Y. 1901) 108 Fed. 816.

30 Greene v. Henkel (1902) 183 U.S. 249. 
ants' evidence on this point. The court also held that the objections to the manner in which the grand jury had been organized might not be entertained in the removal proceeding but were for the trial court.

It was not until 1907 that the Supreme Court for the first time definitely expressed a view on the question whether an indictment constitutes conclusive, or is merely prima facie, evidence of probable cause. It adopted the latter position and held that the accused in a removal proceeding is entitled to offer evidence to controvert the prima facie case of probable cause made out by the indictnent. ${ }^{31}$ In 1926, the Supreme Court in an opinion rendered by Mr. Justice Holmes expressed a contrary view. It held that the commissioner is not intended to hold a preliminary trial and that if probable cause is shown on the governnient's side, he is not to set it aside because on other evidence he believes the defendant innocent. In the case before the court the commissioner had excluded evidence offered by the defendant on the issue of probable cause. The commissioner had indicated that he was not called on to listen to defensive proof. The Supreme Court reached the conclusion that this ruling would not be enough to invalidate the order of removal, as the commissioner had indicated by his findings that he thought there were substantial grounds for the charge of guilt and that it was not for him to decide whether they had been met by the defendants' denials, even if the latter seemed convincing. ${ }^{32}$ On the basis of this decision, a number of lower courts subsequently held that in a removal proceeding the defendant had no legal right to introduce evidence on the issue of probable cause and that the exclusion of such evidence by the commissioner was not error. ${ }^{33}$ The latest decision of the Supreme Court on the point under discussion was rendered in 1935 in United States ex rel. Kassin $v$. Mulligan ${ }^{34}$ in which the court held that the indictment is not conclusive, but that the accused had the right to introduce evidence on the issue of probable cause in opposition to the showing made against him.

Assuming that the indictment is only prima facie proof of probable cause, sufficient to justify renoval in the absence of other evidence on this issue, but that the defendant has the right to offer

31 Tinsley v. Treat (1907) 205 U.S. 20. This case was followed in Hastings v. Murchie (C. C. A. 1st, 1915) 219 Fed. 83 and numerous other cases.

32 United States ex rel. Hughes v. Gault, supra note 1.

33 United States v. Wood (N.D. Tex. 1927) 26 F. (2d) 908; United States ex rel. Millmond v. Fetters (C. C. A. 3d, 1931) 46 F. (2d) 997.

34 Supra note 1. 
evidence in his own behalf to controvert the prima facie case, intricate questions still arise in connection with the construction and application of this doctrine. The decisions on these aspects of the subject are far from clear and are not at unison. Considerable divergence and some confusion are found in the authorities.

The first problem arises in determining the precise meaning of the term "prima facie case". Does the indictment give rise to a presumption of probable cause, which, however, disappears as soon as evidence is offered to controvert it, or is it the type of presumption that remains throughout the case? Manifestly considerable weight and importance must be attached to an indictment, since it is based on a finding of a grand jury, reached on the basis of evidence, that there is prima facie proof of the defendant's guilt and expresses the conclusion of the grand jury that he should be brought to trial. By far the better doctrine is, therefore, that the indictment creates a presumption of probable cause, which remains throughout the proceeding, and that only a strong showing can overcome this presumption. ${ }^{35}$ On the other hand, there are a few cases which hold that if the defendant offers sufficient evidence which apparently meets the prima facie case, it becomes the duty of the prosecution to adduce additional aliunde proof of reasonable cause. ${ }^{38}$

The second problem that has created considerable difficulty is the quantum of proof sufficient to overcome the presumption of probable cause arising from the indictment. It has been held that proof of innocence is not sufficient, because it, im effect, amounts to no more than a plea of not guilty. ${ }^{3 T}$ It has also been stated that the defendant's proof must be overwhelming in order to justify a finding that no probable cause was established in a case in which the removal is sought on the basis of an indictment. ${ }^{38}$ Assuming that the defendant is to be accorded the right to rebut the presumption of probable cause made out in the indictment, it may well be asked what stronger evidence he can adduce than affirmative proof of his innocence. To permit a defendant who has been indicted to offer proof that the charge is not well founded, before any other tribunal than the trial court and on any other occasion than at the trial on the merits, results in a

35 Ross v. Toombs (C. C.A. 5th, 1934) 68 F. (2d) 154; United States ex rel. Steneck v. Levy (N.D. Il. 1925) 3 F. (2d) 816.

38 United States v. Andrade, supra note 24 ; Johnson v. Hotchkiss (C. C. A. 9th, 1929) 35 F. (2d) 914.

3i Swan v. United States (C. C. A. 3d, 1927) 23 F. (2d) 148.

38 United States ex rel. Schmidt v. Bates (C. C. A. 6th, 1938) 95 F. (2d) 881. 
curious anomaly. This may be the explanation why the well-considered cases indicate that only in the exceptional case in which the defendant's affirmative proof is overwhelming, will removal be denied if he has been indicted in the district to which removal is sought. Some decisions have developed a special doctrine for cases of conspiracy in which there are multiple defendants and have held that if a defendant whose removal is desired affirmatively establishes that he had no connection with the conspiracy, this circumstance is sufficient to justify his discharge. ${ }^{39}$

Although the commissioner and the court may consider the issue of probable cause, the scope of the proceeding does not extend to defensive matters, such as, for example, the statute of limitations. Questions of this type are not open for consideration, but must be remitted to the trial court for decision. ${ }^{40}$ Objections based on irregularities in drawing and organizing the grand jury and the illegality of proceedings before the grand jury, likewise may not be entertained at the removal hearing. ${ }^{41}$ If federal jurisdiction is predicated on the contention that the offense was committed on a federal reservation and there is a controverted question whether the place was in fact a federal reservation, this matter may not be determined in the removal proceedings, but should be left for decision by the trial court.

39 United States ex rel. Mayer v. Glass (C. C. A. 3d, 1928) 25 F. (2d) 941; Jeffries v. Lillard (C. C. A. 6th, 1928) 27 F. (2d) 230.

40 Greene v. Henkel, supra note 30; Beavers v. Henkel (1904) 194 U. S. 73; Smith v. Gross (C.C.A. 5th, 1924) 2 F. (2d) 507.

41 United States v. Dumas (E. D. N. Y. 1923) 288 Fed. 247; Smith v. Gross, supra note 40; United States ex rel. Greenberg v. Epstein (E. D. N. Y. 1929) 33 F. (2d) 128; Cochran v. Esola, supra note 25 . But see United States v. Black (C. C. A. 7th, 1908) 160 Fed. 431.

42 Rodman v. Pothier (1924) 264 U.S. 399. In the case of In re Dana, Fed. Cas. No. 3554, decided in the Southern District of New York in 1873, it was sought to remove Charles A. Dana, the Editor and Publisher of the New York Sun, to the District of Columbia for trial on a libel charge instituted by an information filed in the Police Court of the District of Columbia, in which at that time trials were without a jury with a right to appeal to tbe Supreme Court of the District of Columbia, where a jury trial de novo could be had. The court denied the application for removal on the ground that the defendant had a constitutional right to a jury trial in the first instance and that the mode of trial provided by the District of Columbia statute was unconstitutional. The judge stated: "As therefore the defendant if removed to the District of Columbia vrill be tried in a .manner forbidden by the Constitution I must decline to grant the warrant." This disposition must be regarded as unique and exceptional and the case does not appear to have been followed. In a case decided in the District of Maryland in 1884 , in which the same objection was raised, removal was granted. In re Cross 20 Fed. 824. 
An examination of the decisions leads to the inference that the number of instances in which applications for removal are denied form but a minute fraction of all cases in which removal is sought. On the other hand, removal proceedings are a common source of obstructive and dilatory tactics on the part of the accused and frequently lead to protracted delays in bringing the defendant to trial, much to the discomfiture of the administration of justice. A few glaring illustrations demonstrate the existence of this serious defect in federal criminal procedure. In the case above mentioned, ${ }^{43}$ in which Captain Oberlin M. Carter and a number of codefendants were charged with conspiracy to defraud the United States, the indictment was returned in the Southern District of Georgia on December 8, 1899. A warrant of arrest against some of the defendants residing in the Southern District of New York was issued on December 13, 1899. After a hearing before a commissioner, who committed the defendants, the judge on April 4, 1900, denied removal without prejudice. Hearings before the commissioner were reopened and a great deal of testimony was taken. Again the commissioner found probable cause and committed the defendants. On May 15, 1901, the judge issued a warrant of removal. An application to the circuit court for a writ of habeas corpus followed and the case reached the Supreme Court on an appeal from an order denying the writ. On January 6,1902, the court affirmed the order. In other words, over two years were consumed in securing the removal of several defendants from New York to Georgia for trial.

In a more recent case, one Weinberger was indicted in the Southern District of New York in June, 1931, on a charge of using the mails to defraud. He was arrested in New Jersey. Removal proceedings were instituted against him, but were prolonged by numerous hearings and appeals until December 1933, when his removal to New York was finally accomplished. In other words, a period of approximately two and a half years elapsed between indictment and removal of the defendant a few miles from New Jersey to New York for trial. ${ }^{44}$

The files of the federal courts abound in many other cases in which somewhat similar delays have occurred, but the foregoing examples are sufficient to illustrate some of the disadvantages of the traditional removal procedure, and the necessity for elimination of

\footnotetext{
43 United States v. Greene, supra note 28; United States v. Greene, supra note 29; Greene v. Henkel, stupra note 30 .

44 United States v. Weinberger (N. J. 1933) 4 Fed. Supp. 892 ; See House Rep. No. 1543, 75th Cong. (Aug. 13, 1937).
} 
technicalities and other improvements. One source of delay was extirpated in 1938 by an Act of Congress abolishing the right of appeal from an order in a habeas corpus proceeding brought to test the validity of a warrant of removal. ${ }^{45}$

The Act of June 29, $1940^{46}$ empowered the Supreme Court to regulate criminal procedure in the United States district courts. To assist in the preparation of the criminal rules, the Supreme Court appointed an Advisory Committee, which found itself confronted with the foregoing background in its studies of the subject of removal. It became evident that this branch of the law needed complete revamping and drastic modification. The Committee drafted a rule which radically revised and modernized removal procedure. The proposed rule was adopted by the Supreme Court.

The new practice is outlined in Rule 40 of the Federal Rules of Criminal Procedure for the District Courts of the United States, which were prescribed by the Supreme Court on December 26, 1944, and reported to the Congress on January 3, 1945. The rules become effective three months subsequent to the adjournment of the present session of the Congress, but if that day is prior to September 1, 1945, then they take effect on September 1, 1945. ${ }^{47}$

The real purpose of removal proceedings is to protect the accused against transportation to a distant point for trial on a charge improvidently made. For this reason, they seem to have no place if the removal involves only a comparatively short distance. In the light of these considerations the new rule introduces a marked innovation. It segregates into two distinct categories all cases in which the defendant is arrested in a district other than that in which the prosecution is pending. In the first group are arrests in "nearby districts", while the second class comprises arrests in "distant districts". In the first class are placed all cases in which the arrest is made in the state in which the prosecution has been instituted, although in a different district. In addition, it includes all cases in which the arrest is made within one hundred miles of the place of trial, even though in a different state. For all arrests in "nearby districts", removal proceedings are abolished entirely. The defendant will of course have the same right to a preliminary hearing before a committing magistrate as he would have if the arrest were made in the district in which the prosecution

4552 STAT. (1938) 1232, 28 U.S.C. (1940) § 463 a.

4654 Stat. 688, 18 U.S. C. (1940) § 687.

4i H. R. Doc. No. 12, 79th Cong. 1st Sess. (1945). 
was instituted. If however, the commissioner holds the defendant, the latter would be bound over for appearance before the court in which the case is pending. No application for a warrant of removal would be necessary. The basis for this treatment of the subject is that in the state courts there is nothing resembling or analogous to a removal proceeding as between different parts of the same state. A defendant apprehended at one end of a state on a warrant issued in another county at the other end of the state is forthwith taken by the arresting officer before the tribunal which issued the process. No separate warrant authorizing the transportation is required. It seemed proper that the territorial extent of federal authority in such a matter should be at least coterminous with that of the states. Cases involving arrests made in another state, but within one hundred miles from the place of trial, were also included, in order to avoid the possibility of a defendant intentionally crossing a state line, taking refuge at a nearby point in the adjoining state, and defying the authorities to remove him, thereby at times securing an unconscionable delay in the trial of the case. As has been indicated above, abuses of this type have actually occurred and should be made impossible.

In the second category, i.e. arrests in "distant districts", are found those cases in which the arrest is made in a state other than that in which the prosecution is pending and the place of arrest is one hundred miles or more froin the place of trial. It is reasonable to accord to a defendant some protection against possible hardships caused by an improvident removal to a distant point. First, it is necessary to assure that the prisoner is actually the person charged with the of fense in the district in which the prosecution originated. Second, it is proper and fitting that in such cases reasonable cause to believe the defendant guilty of an of fense against the laws of the United States should be established, before removal is ordered. Because of these considerations removal proceedings are preserved for cases in this class. These cases are still further subdivided into two groups: first, those in which the basis of the prosecution is a complaint before a committing magistrate or an information filed in court by the United States attorney; and second, those in which removal is sought on the basis of an indictment. In cases of the first type, the prosecution, in addition to proof of identity, will be required to adduce evidence of probable cause to believe that the defendant is guilty of the offense charged. The accused will be entitled to introduce evidence in his own behalf. On the other hand, if the prosecution is based on an indictment, a certified 
copy of the indictment will be conclusive proof of probable cause and the only additional evidence required will be proof of identity. The defendant will not be entitled to controvert the indictment. This provision of the rule will definitively settle the question whether an indictment is prima facie or conclusive proof of probable cause. The latter alternative was selected because of the fact that in such cases the grand jury had heard the evidence and found that there was probable cause for putting the accused on trial. Since the action of the grand jury is not subject to review by the court of which it is an arm, it seemed appropriate that the court for the district in which the defendant may have been fortuitously apprehended should not be clothed with any greater authority in this regard.

The observation may be ventured that the new rule introduces much needed reforms and some desirable novelties in the traditional removal procedure, which has grown up gradually into a somewhat amorphous structure. The new practice, while according safeguard to the defendant against possible oppression and improvident action on the part of the prosecuting branch of the government, at the same time deprives him of a weapon which has been used for delaying and obstructing the expeditious and orderly disposition of criminal cases. The procedure prescribed by the rule is likely to result in a marked improvement in the administration of justice. 